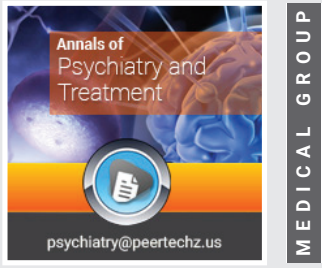

\section{Clinical evidence in sexual orientations: definitions, neurobiological profiles, and psychological implications}

\section{Giulio Perrotta*}

Psychologist sp.ing in Strategic Psychotherapy, Forensic Criminologist, Legal Advisor sp.ed SSPL, Researcher, Essayist, Institute for the study of psychotherapies - ISP, Via San Martino della Battaglia no. 31, 00185, Rome, Italy
Received: 12 April, 2021

Accepted: 22 June, 2021

Published: 23 June, 2021

*Corresponding author: Dr. Giulio Perrotta, Psychologist sp.ing in Strategic Psychotherapy, Forensic Criminologist, Legal Advisor sp.ed SSPL, Researcher, Essayist, Institute for the study of psychotherapies - ISP, Via San Martino della Battaglia no. 31, 00185, Rome, Italy, E-mail: info@giulioperrotta.com Keywords: Homosexuality; Bisexuality; Heterosexuality; Bi-curiosity; Asexuality; Pansexuality; PICI-1; PSM-1

https://www. peertechzpublications.com

Check for updates

\title{
Abstract
}

Purpose: The aim of this research is to detect any clinical evidence in patients on the basis of their sexual orientation choice. The starting hypothesis, taking into account the neurobiological and endocrinological data of the last twenty years on the subject of sexual orientation, is to demonstrate an increase in psychopathological indexation in non-heterosexual patients, and then to detect among the possible psychological causal hypotheses which indicators are most present in the individual clinical history, in order to demonstrate that sexual orientation other than heterosexuality is an adaptation to a previous psychological trauma with a strong emotional and sexual impact. This research work aims to answer the following one question: "Are there any dysfunctional psychological factors that occur more frequently in any of the five identified groups?".

Methods: Clinical interview and administration of the PICI-1 and PSM-1.

Results: In the male heterosexual group, the psychopathological values were $43.96 \%$, with a greater presence of neurotic disorders, while in the female heterosexual group, the values were $57.27 \%$, with the same majority found in the male group. In the male homosexual group, the psychopathological values were $66 \%$, with a greater presence of neurotic disorders, while in the female homosexual group, the values were $76.97 \%$, with the same majority found in the male group. In the male bisexual group the psychopathological values were $76.44 \%$, with a greater presence of neurotic disorders, while in the female bisexual group the values were $70 \%$, with the same majority as in the male group. In the groups related to the other sexual orientations (bi-curiosity, asexuality and pansexuality), none of the respondents ticked "None of the above", thus endorsing the thesis that at least one of these factors could be a concomitant cause of the onset of non-heterosexual preference. With reference to the results obtained from the PSM-1, to the question "Are there dysfunctional psychological factors that occur more frequently?" the ticking of "None of the above" emerges in half of the respondents and tends to decrease to zero in the non-heterosexual orientations, confirming the trend already underlined.

Conclusions: The topic under consideration is very thorny, more for its socio-political implications than for its clinical ones. Here, in fact, is not at stake any judgment of merit or form, but the exact clinical placement in the cognitive and experiential framework. These considerations are completely detached and far from any form of judgment or condemnation ethical, moral, social and personal. On the subject of the pathologization of sexual orientations other than heterosexuality, between the two theses under discussion (confirmation, on the one hand, or disconfirmation, on the other), this research suggests the "median" position that on the one hand confirms the non-pathological nature of sexual orientations other than heterosexuality in itself (since there is no scientific evidence to the contrary), but on the other confirms the hypothesis that, on the basis of the person's experience, psychopathological conditions can coexist that require psychotherapeutic intervention, regardless of the orientation in itself. In conclusion, therefore, significant data emerge from this research in favor of the psychological etiological hypothesis (even if the writer adheres to the multi-causal hypothesis) according to which in sexual orientations other than heterosexuality there is a marked indexation of psychopathological and dysfunctional traits compared to the heterosexual group, with the presence of causal indicators identified in PSM-1 in increasing numbers in the same non-heterosexual groups. These data would support the hypothesis that non-heterosexual orientations could actually be the adaptive consequence of a psychological trauma, with a strong emotional and sexual impact (including abuse, violence, neurobiological, hormonal, and somatic predispositions, affective-emotional dysregulation with reference figures, and socioenvironmental and family readjustments), in itself therefore not pathological but circumstances favoring negative and unfavorable dynamics, of social and environmental matrix, such as to favor or aggravate psychopathological conditions, including mood, depressive, obsessive, somatic, personality and suicidal disorders. 


\section{Contents of the manuscript}

\section{Introduction and background}

In the last thirty years, neurosciences have been very interested in the study of the correlation between sexual orientation (intended as a form of emotional, sentimental and / or sexual attraction of a person to another person regardless of the biological sex of belonging or his sexual identity) and certain neurobiological and neurophysiological components, capable of demonstrating the existence or otherwise of the direct relationship. Sexual orientation, properly so called, is therefore a lasting model towards another subject. From the second half of the twentieth century, the first idea of "homosexuality" was declassified, moving from the psychopathological condition inherent to the sociopathic personality disorders of the 1954 version of the Diagnostic and Statistical Manual of Mental Disorders (DSM) to the sexual deviance of 1968, only to gradually become an ego-dystonic form of one's own in 1974 sexual perception and finally a natural sexual orientation only in 1987 and in the revised version of 1990 , being finally decriminalized reeds by the International Statistical Classification of Diseases, Accidents and Causes of Death (ICD) of 17 May 1990, although psychoanalytic thinking was well oriented towards the opposite; in fact, homosexuality had hitherto been considered a "morbid obsession" (Charcot), a "sexual psychopathy" (von KrafftEbing), an "arrest of normal development" (S. Freud), a "narcissistic fixation" (Ferenczi), a "neurotic escape" (Adler) or a "parapathic neurosis that originates from the conflict between instinct and inhibition" (Stekel). However, this evolution has certainly led to an opening towards social rights but also to a fluidity in sexual orientation, where the main problems emerge especially in the bisexual position [1]. The legal status of homosexual relationships varies enormously from one state to another and there still remain jurisdictions in which some homosexual behavior is considered a crime and punished with severe penalties (imprisonment), up to capital punishment (death); this still happens in many African and Middle Eastern countries. Sexual orientation is therefore commonly debated as a characteristic of the individual, as well as for biological sex, gender identity or age. However, this perspective is incomplete, since sexual orientation is always defined on the basis of relational terms and necessarily concerns relationships with other individuals. Sexual acts and romantic attractions are categorized as homosexual or heterosexual based on the biological sex of the individual involved in them, relative to the partners. Indeed, it is through performance - or the desire to lend - with another person that individuals express their heterosexuality, homosexuality or bisexuality. Thus, sexual orientation is fully connected to the intimate personal relationships that human beings form with others to meet their deepest sentimental needs for love, bond and intimacy. In addition to sexual behavior, these constraints include not-sexual physical affections between partners, sharing goals and values, mutual support and constant commitment. Consequently, sexual orientation is not merely a personal characteristic that can be defined in isolation. Likewise, one's sexual orientation defines the universe of people with whom a person is able to find satisfying and fulfilling relationships which, for many individuals, comprise an essential component of personal identity [1-67].

From a neurobiological point of view, robust evidence shows that between heterosexual and homosexual brains, there are significant structural and functional differences in different areas (thalamus, hypothalamus, basal ganglia, amygdala, corpus callosum, frontal lobe, grey matter and cerebral cortex) [68-97]; more than interesting, the analyzes regarding these directly related aspects appear, contextualising: any differences between the "homosexual tendency" (determined perhaps by paraphilic or post-traumatic adaptive factors) and the precise and conscious decision to perceive one's balance in the "homosexual or bisexual condition" (therefore the de facto choice of orientation); any that allow to clearly distinguish comorbid conditions (such as anxiety disorders, eating disorders, depressive disorders, panic, obsessions, behavioral addictions and suicidal risk) from the choice homosexual or bisexual (and whether the latter is able to feed the comorbid conditions); the differences between highly adaptive and functional conditions from those that cause the patient to feel unwell and dysfunctional [98-106].

The direct and indirect implications on the confirmation of the clinical hypothesis of the homosexual and / or bisexual condition would bring further complications, with reference to the management of the patients' treatments and therapies, while making important differences between highly adaptive patients and those who perceive their condition as dysfunctional with respect to the surrounding environment. The question to ask, in this theoretical hypothesis, is whether we must actually intervene clinically to correct the homosexual or bisexual condition and lead the patient towards a heterosexual orientation, or simply accompany him towards a better perception of his emotions, desires and needs strategically [107-109].

\section{Research objectives and methods}

Starting therefore from the psychological aetiological hypothesis, as stated in the introduction to this research work, that sexual orientations other than homosexuality could in reality be the consequence of an adaptation to particularly destabilising traumatic events in the emotional and family sphere of the person, the present research aims to identify the possible psychological causes capable of justifying a preference other than heterosexuality.

For the purposes of this research, other possible causes that are not directly linked to a psychological nature are therefore excluded.

In order to facilitate the research work, a specific questionnaire (Perrotta Individual Sexual Matrix Questionnaire, $P S M-1)$ [110] has been selected, capable of providing anamnestic information and data on the emotional, emotional and family sphere, which will be submitted to the selected sample of the population together with the Perrotta Integrative Clinical Interview, PICI-1 (TA version) [11-113], taking into account the age, in order to facilitate the identification of 
any psychopathologies or dysfunctional personality traits not declared by the respondent.

The phases of the research were divided as follows:

1) Selection of the population sample divided into six groups $(\mathrm{A}, \mathrm{B}, \mathrm{C}, \mathrm{D}, \mathrm{E}, \mathrm{F})$ as indicated in section 3 of this research work.

2) Administration of the PICI-1 to each population group.

3) Data processing following administration.

4) Administration of the PSM-1 (sections A, B, C, D), to each population group.

5) Data processing following administration.

6) Comparison of data obtained.

This research work aims to answer the following one question: Are there any dysfunctional psychological factors that occur more frequently in any of the five identified groups?

\section{Setting and participants}

The requirements decided for the selection of the sample population are:

1) Age between 18 years and 75 years.

2) Italian nationality, with Italian ancestors in the last three generations.

3) Sexually active, with experience of at least 2 years.

4) Specific declaration of sexual orientation.

The selected setting, taking into account the protracted pandemic period (already in progress since the beginning of the present research), is the online platform via Skype and Videocall Whatsapp, both for the clinical interview and for the administration.

The present research work was carried out from April 2020 to December 2020.

The selected population sample is 1430 participants, divided into six groups:

A) Heterosexuality (attraction to people of the opposite sex), in total of 818 and divided into: 380 males and 438 females.

B) Homosexuality (attraction to people of the same sex), in total of 470 and divided into: 414 males and 56 females.

C) Bisexuality (attraction to people of both main sexes), in total of 88 and divided into: 68 males and 20 females.

D) Bi-curiosity (attraction to people of both main sexes, while identifying with heterosexuality), in total of 26 and divided into: 20 males and 6 females.

E) Asexuality (little or no interest in sexuality or lack of identification), in total of 16 and divided into: 10 males and 6 females.

F) Pansexuality (attraction regardless of identity and orientation), in total of 12 and divided into: 4 males and 8 females.

\begin{tabular}{|c|c|c|c|}
\hline & Male & Female & Total \\
\hline Heterosexuality & 380 & 438 & 818 \\
\hline Homosexuality & 414 & 56 & 470 \\
\hline Bisexuality & 68 & 20 & 88 \\
\hline Bi-curiosity & 20 & 6 & 26 \\
\hline Asexuality & 10 & 6 & 16 \\
\hline Pansexuality & 4 & 8 & 12 \\
\hline Total & 896 & 534 & 1430 \\
\hline
\end{tabular}

All participants were guaranteed anonymity.

\section{Results, limits and possible conflicts of interest}

After the selection of the chosen population sample (first stage), the PICI-1(TA) results were administered (second stage) and processed (third stage), obtaining the following results:

\begin{tabular}{|c|c|c|c|c|}
\hline & Male & $\mathrm{PICI}-1$ results $(\mathrm{M})^{\star}$ & Female & PICl-1 results $(\mathbf{F})^{*}$ \\
\hline Heterosexuality & 380 & $\begin{array}{c}\text { Cluster A }=82(22,96 \%) \\
\text { Cluster B }=67(18,76 \%) \\
\text { Cluster C }=8(2,24 \%)\end{array}$ & 438 & $\begin{array}{c}\text { Cluster } A=138(31,74 \%) \\
\text { Cluster } B=101(23,23 \%) \\
\text { Cluster } C=10(2,3 \%)\end{array}$ \\
\hline Homosexuality & 414 & $\begin{array}{c}\text { Cluster } A=173(41,52 \%) \\
\text { Cluster B }=93(22,32 \%) \\
\text { Cluster C }=9(2,16 \%)\end{array}$ & 56 & $\begin{array}{c}\text { Cluster } A=31(55,49 \%) \\
\text { Cluster } B=9(16,11 \%) \\
\text { Cluster } C=3(5,37 \%)\end{array}$ \\
\hline Bisexuality & 68 & $\begin{array}{c}\text { Cluster A }=26(38,22 \%) \\
\text { Cluster B }=22(32,34 \%) \\
\text { Cluster C }=4(5,88 \%)\end{array}$ & 20 & $\begin{array}{l}\text { Cluster } A=8(40 \%) \\
\text { Cluster } B=5(25 \%) \\
\text { Cluster } C=1(5 \%)\end{array}$ \\
\hline Bi-curiosity & 20 & $\begin{array}{c}\text { Cluster } A=9(45 \%) \\
\text { Cluster } B=3(15 \%) \\
\text { Cluster C }=0\end{array}$ & 6 & $\begin{array}{c}\text { Cluster } A=2(33,34 \%) \\
\text { Cluster } B=1(16,67 \%) \\
\text { Cluster } C=0\end{array}$ \\
\hline Asexuality & 10 & $\begin{array}{c}\text { Cluster } A=0 \\
\text { Cluster B }=6(60 \%) \\
\text { Cluster C }=4(40 \%)\end{array}$ & 6 & $\begin{array}{c}\text { Cluster A }=0 \\
\text { Cluster B }=3(50 \%) \\
\text { Cluster C = } 3(50 \%)\end{array}$ \\
\hline Pansex & 4 & $\begin{array}{c}\text { Cluster A = } 0 \\
\text { Cluster B = } 3(75 \%) \\
\text { Cluster C = } 1(25 \%)\end{array}$ & 8 & $\begin{array}{c}\text { Cluster A }=0 \\
\text { Cluster B = } 6(75 \%) \\
\text { Cluster C = } 2(25 \%)\end{array}$ \\
\hline
\end{tabular}

*For the PICl-1(TA), cluster A groups disorders of the neurotic area, cluster $\mathrm{B}$ groups borderline disorders and cluster $\mathrm{C}$ groups disorders of the psychotic area

Subsequently, the same sample of the population was subjected (fourth stage) to the PSM-1 (sections A, B, C, D) and data processing (fifth stage). The last phase of the research (sixth phase) focused on comparing the data obtained during the third and fifth phases. Indeed, the results are:

The limitations of the research are mainly centred on the non-representative sample with respect to minority sexual orientations, due to difficulties in finding participants; however, given the exceptional nature of the results obtained, the writer suggests greater attention be paid to the subject, perhaps with a more representative sample of the population. In addition, the PICI-1 and PSM-1 are not yet standardised psychometric instruments but are proposed, despite the excellent results obtained and already published in international scientific journals [111-113]. 


\begin{tabular}{|c|c|c|c|c|c|c|}
\hline \multirow[b]{2}{*}{ Heterosexuality } & \multirow{2}{*}{$\begin{array}{c}\text { Male (M) } \\
380\end{array}$} & \multicolumn{2}{|c|}{ PSM-1 results $(\mathrm{M})$} & \multirow{2}{*}{$\begin{array}{c}\text { Female (F) } \\
438\end{array}$} & \multicolumn{2}{|c|}{ PSM-1 results (F) } \\
\hline & & $\begin{array}{l}1 * \\
2 * \\
3 * \\
4^{\star} \\
5^{\star} \\
6 * \\
7 * \\
8 *\end{array}$ & $\begin{array}{c}23(6,1 \%) \\
50(13,1 \%) \\
21(5,6 \%) \\
47(12,6 \%) \\
21(5,5 \%) \\
1(0,3 \%) \\
21(5,7 \%) \\
196(51,1 \%)\end{array}$ & & $\begin{array}{l}1^{\star} \\
2^{\star} \\
3^{*} \\
4^{\star} \\
5^{\star} \\
6 * \\
7^{*} \\
8^{*}\end{array}$ & $\begin{array}{c}38(8,6 \%) \\
65(14,9 \%) \\
21(4,7 \%) \\
37(8,4 \%) \\
15(3,3 \%) \\
0 \\
45(10,2 \%) \\
217(49,9 \%)\end{array}$ \\
\hline Homosexuality & 414 & $\begin{array}{l}1^{\star} \\
2^{\star} \\
3^{\star} \\
4^{\star} \\
5^{\star} \\
6^{*} \\
7^{\star} \\
8^{*}\end{array}$ & $\begin{array}{c}61(14,7 \%) \\
40(9,6 \%) \\
83(19,9 \%) \\
103(24,7 \%) \\
20(4,8 \%) \\
2(0,6 \%) \\
71(17,2 \%) \\
34(8,2 \%)\end{array}$ & 56 & $\begin{array}{l}1^{*} \\
2^{*} \\
3^{*} \\
4^{*} \\
5^{*} \\
6^{*} \\
7^{*} \\
8^{*}\end{array}$ & $\begin{array}{c}16(28,6 \%) \\
10(17,9 \%) \\
8(14,3 \%) \\
7(12,5 \%) \\
2(3,5 \%) \\
1(1,7 \%) \\
8(14,3 \%) \\
4(7,2 \%)\end{array}$ \\
\hline Bisexuality & 68 & $\begin{array}{l}1 * \\
2 * \\
3 * \\
4^{\star} \\
5^{\star} \\
6 * \\
7 * \\
8^{\star}\end{array}$ & $\begin{array}{c}15(22,1 \%) \\
21(30,8 \%) \\
11(16,2 \%) \\
9(13,3 \%) \\
3(4,5 \%) \\
1(1,4 \%) \\
8(11,7 \%) \\
0\end{array}$ & 20 & $\begin{array}{l}1^{\star} \\
2^{\star} \\
3^{*} \\
4^{\star} \\
5^{\star} \\
6 * \\
7^{*} \\
8^{*}\end{array}$ & $\begin{array}{c}3(15 \%) \\
3(15 \%) \\
4(20 \%) \\
4(20 \%) \\
1(5 \%) \\
0 \\
5(25 \%) \\
0\end{array}$ \\
\hline Bi-curiosity & 20 & $\begin{array}{l}1^{\star} \\
2^{\star} \\
3^{\star} \\
4^{\star} \\
5^{\star} \\
6^{*} \\
7^{\star} \\
8^{\star}\end{array}$ & $\begin{array}{c}1(5 \%) \\
3(15 \%) \\
3(15 \%) \\
2(10 \%) \\
3(15 \%) \\
0 \\
8(40 \%) \\
0\end{array}$ & 6 & $\begin{array}{l}1^{*} \\
2^{*} \\
3^{*} \\
4^{*} \\
5^{*} \\
6^{*} \\
7^{*} \\
8^{*}\end{array}$ & $\begin{array}{c}1(16,67 \%) \\
1(16,67 \%) \\
1(16,67 \%) \\
2(33,32 \%) \\
0 \\
0 \\
1(16,67 \%) \\
0\end{array}$ \\
\hline Asexuality & 10 & $\begin{array}{l}1 * \\
2 * \\
3 * \\
4^{\star} \\
5^{\star} \\
6 * \\
7 * \\
8 *\end{array}$ & $\begin{array}{c}3(30 \%) \\
0 \\
2(20 \%) \\
2(20 \%) \\
0 \\
0 \\
3(30 \%) \\
0\end{array}$ & 6 & $\begin{array}{l}1 * \\
2 * \\
3 * \\
4^{\star} \\
5^{\star} \\
6 * \\
7 * \\
8^{*}\end{array}$ & $\begin{array}{c}2(33,34 \%) \\
0 \\
1(16,67 \%) \\
1(16,67 \%) \\
0 \\
0 \\
2(33,34 \%) \\
0\end{array}$ \\
\hline Pansexuality & 4 & $\begin{array}{l}1^{\star} \\
2^{\star} \\
3^{\star} \\
4^{\star} \\
5^{\star} \\
6^{*} \\
7^{\star} \\
8^{\star}\end{array}$ & $\begin{array}{c}1(25 \%) \\
0 \\
1(25 \%) \\
1(25 \%) \\
0 \\
0 \\
1(25 \%) \\
0\end{array}$ & 8 & $\begin{array}{l}1^{*} \\
2^{*} \\
3^{*} \\
4^{*} \\
5^{*} \\
6^{*} \\
7^{*} \\
8^{*}\end{array}$ & $\begin{array}{c}2(25 \%) \\
0 \\
2(25 \%) \\
2(25 \%) \\
0 \\
0 \\
2(25 \%) \\
0\end{array}$ \\
\hline
\end{tabular}

* 1. Sexual abuse or physical violence in childhood and/or preadolescence; 2. Psychological abuse with a sexual connotation (coercion and/or submission) in childhood and/ or preadolescence; 3. Dysfunctional caring on the part of the caregiver during the attachment period (0-6 years); 4. Unbalanced intra-parental relationship; 5 . Overexposure to pornography in childhood and/or preadolescence; 6 . Clinically certified sex hormone imbalance; 7 . Cetified medical history of one or both parents of severe mental and/or personality disorders; 8 . None of the above.

Since the research is not financed by anyone, it is free of conflicts of interest.

\section{Are non-heterosexual sexual orientations to be consi- dered pathological?}

The current generally accepted clinical position on homosexuality and other orientations other than heterosexuality [1], since the 1970 s, is to consider them not pathological but simply a normal variation of sexual behavior; in particular, the American Psychiatric Association (APA), in 1973, removed homosexuality from the list of mental pathologies, based on two main considerations: a) Pathologizing had mistakenly occurred as a result of adherence to the psychodynamic ideal that imposed the thesis on the biological and natural approach, according to which sexual reproduction could only occur exclusively between two persons of the opposite sex. This theoretical approach has conditioned scientific and literary thought, crystallizing in 1952, in the DSM psychodiagnostic manual, in the form of "sociopathic personality disorder" and in 1968 in the form of "sexual deviation" (like the current paraphilias). With the advent of the 1970s, the basic idea was to depathologize homosexuality by first distinguishing between 
"egosyntonic homosexuality" and "egodistonic homosexuality" (on the basis of the more or less serene acceptance of one's position); in this sense, in the third edition of the manual, only the egosyntonic form was first removed, precisely because it was accepted by the patient. Finally, only in 1987 and in the revision of 1993 was also definitively eliminated the wording egodystonic to promote the total depathologizing. With the advent of a global revision of psychoanalytic thought, strongly critical of homosexuality, this process could be favored.

b) The idea that homosexuality and in general any other orientation different from heterosexuality can be pathological is not supported by any scientific data but only by theoretical elaborations of classical psychoanalytic thought, which then laid the groundwork (along with the elaborations of cognitivebehavioral thought) to found the clinical approach of psychopathologies.

On the contrary, those who support the pathological nature state that $[1,114-116]$ :

a) The psychodynamic approach represents the foundation of world psychological thought, and therefore its theorizations are still valid and considered shareable today (and therefore it is not clear why on homosexuality such assumptions are considered wrong).

b) The depathologization has been a process decided at the table, by a commission of experts, without making use of scientific data, but on the basis of an attack to the psychoanalytic foundations and on the basis of a strong social and political drive resulting from the uprisings of ' 68 , considering that the empirical research produced in support of the thesis of depathologizing homosexuality, such as Hooker's studies, had been conducted with population samples (30 heterosexuals and 30 homosexuals) far from being considered relevant, statistical and representative [116-146].

c) Depathologizing has normalized a sexual behavior that, in the extreme, if it were applicable to all human beings, would have led to the extinction of man, because in the absence of heterosexual reproductive couplings, the human race could not continue to exist in the medium to long term.

d) Recent neurobiological studies have shown, in selected population samples, a significant structural and functional difference of the encephalon between heterosexuals and homosexuals, outlining a marked hypofunctionality or hyperfunctionality of certain areas; conditions that, if they had been found in selections for the study of psychopathologies, would have significantly confirmed the pathological hypothesis.

The writer, in this regard, in relation to the studies carried out, publications and research results, suggests a position between the two extremes certainly median.
In particular, if on the one hand psychoanalytic theorizations were often speculative and theoretical, on the other hand neurobiological data outline a precise path; just as it is true that the revolutionary movements of ' 68 were the social and political basis that has pushed for a depathologization of homosexuality, it is equally true that the pathological condition is such if it has certain aspects related to the malaise and wellbeing of the individual, clear of generalizations, preconceptions and prejudices.

The writer therefore intends to clarify that in light of the evidence no data currently in the possession of the scientific community demonstrates clearly and incontrovertibly that sexual orientation other than heterosexuality is a pathological condition.

Some data, in particular, in the opinion of the writer, are interesting precisely because of their peculiarity:

The dynamics described by psychoanalysis are the product of an interpretive process that often takes into account rigid theoretical positions and not the actual narrated and experienced by the patient, forcing him to unconscious journeys that do not work on the "here and now", focusing more on the whys and not on the solutions to the proposed problem. In this sense, defining homosexuality as pathological only on the basis of theoretical assumptions is scientifically incorrect.

The depathologizing of homosexuality has been a process without the use of scientific data and on the basis of a strong social and political impetus resulting from the uprisings of '68. Therefore, both pathologizing and declassification lack scientific evidence; on that basis, both could be as correct as incorrect.

The biological hypothesis according to which if we were all homosexuals there would be the extinction of the human race is essentially correct, but this assumption is an extreme theoretical hyperbole that does not take into account internal (psychological) and external (social) conditioned factors; therefore, it has no scientific value to support the biological hypothesis according to this point of view, remaining a simple theoretical speculation.

Recent neurobiological studies have shown, in selected population samples, a significant structural and functional difference of the encephalons between heterosexuals and homosexuals, outlining a marked hypofunctionality or hyperfunctionality of certain areas; conditions that, if they had been found in selections for the study of psychopathologies, would have significantly confirmed the pathological hypothesis. This position is partly correct, because it takes into account scientific evidence but, in the opinion of the writer, does not take into account the fact that almost always the sample of the population selected is not representative, because of the costs of research, and also does not take into account that neurobiological trends can facilitate a certain predisposing dynamic but can not be in itself considered (regardless) pathological for the sole fact of being present. An obvious example is neuroplasticity in psychological trauma 
and the impact of the EMDR technique that is able to "move" the area of trauma to another area following psychological reworking. Certainly, the structural and functional differences found are interesting, but these studies deserve further study before being considered scientific evidence of the morbidity of homosexuality.

Having said this, the writer, in relation to the data obtained from the present study, illustrates the theoretical hypothesis that he defines as "median" with respect to the two poles "pathological - non-pathological". From the PSM-1 it emerges that about $50 \%$ of the sample of heterosexual population did not sign any of the reasons belonging to the list of causes pertaining to section $\mathrm{B}$ of the questionnaire (sexual abuse or physical violence in childhood and/or preadolescence, psychological abuse with a sexual connotation -coercion and/or submissionin childhood and/or preadolescence, dysfunctional caring on the part of the caregiver during the attachment period 0-6 years, unbalanced intra-parental relationship, overexposure to pornography in childhood and/or preadolescence, clinically certified sex hormone, imbalance, cetified medical history of one or both parents of severe mental and/or personality disorders), while in the categories other than heterosexuality this figure tends to decrease progressively until it reaches zero, demonstrating how such causes could be the psychological reasons behind the perceived sexual orientation. In this sense one could "ideally" speak of a "functional adaptation" to one or more psychophysical traumatic events. However, this assumption, even if the sample is representative, cannot explain the phenomenon in its entirety, other than to provide further food for thought on the subject. What remains, from a psychological point of view, is certainly that the central theme is not so much that of understanding the pathological matrix of the orientation as it is that of reasoning about the person's perception and his or her experience, in order to understand whether he or she is in hegosyntony or hegodystonia with respect to his or her emotions and drives. This position, in the opinion of the writer, is "median" because on the one hand it confirms the non-pathological nature of sexual orientations other than heterosexuality (since there is no scientific evidence to the contrary), but on the other hand it confirms the hypothesis that, on the basis of the person's experience, psychopathological conditions can coexist that require psychotherapeutic intervention.

\section{Conclusions}

Processing the data obtained from the selected population sample, the following results emerge:

1) Representativeness of the population sample: Although the population sample in the heterosexual and homosexual groups is significant, it is not sufficiently representative to obtain reliable and valid statistical data, despite the high symbolism of the data obtained. Moreover, the small population sample of subjects who declare themselves to have an orientation that is in any case different from heterosexuality, homosexuality and bisexuality does not allow assessments to be made that have statistical reliability, despite the fact that clear and significant values emerge, such as the total absence of a marking "None of the above" in favour instead of points 1 (sexual abuse or physical violence in childhood and/ or preadolescence), 3 (dysfunctional caring on the part of the caregiver during the attachment period), 4 (unbalanced intraparental relationship) and 7 (cetified medical history of one or both parents of severe mental and/or personality disorders), which are constantly repeated in those groups. If we were to group them together in the "Other orientations" group alone, the data would be more significant, although they would not be representative:

\begin{tabular}{|c|c|c|c|c|c|c|}
\hline & $\mathrm{Ma}$ & (M) & & Fen & le ( & \\
\hline & & 1 * & $5(14,7 \%)$ & & $1 *$ & $5(25 \%)$ \\
\hline & & $2^{*}$ & 3 (8,82\%) & & $2^{*}$ & $1(5 \%)$ \\
\hline & & 3* & $6(17,64 \%)$ & & 3* & $4(20 \%)$ \\
\hline Other sexual & $\Omega$ & $4^{*}$ & $5(14,7 \%)$ & 0 & $4^{\star}$ & $5(25 \%)$ \\
\hline orientationsc & & $5^{\star}$ & 3 (8,82\%) & & $5^{\star}$ & 0 \\
\hline & & 6* & 0 & & 6* & 0 \\
\hline & & 7* & $12(35,28 \%)$ & & 7* & $5(25 \%)$ \\
\hline & & 8* & 0 & & 8* & 0 \\
\hline
\end{tabular}

With such a graphic representation it is easier to make other considerations:

a) Among the proposed causal hypotheses, no respondent initialled the item "None of the above", endorsing the thesis that at least one of those factors may be a concomitant to the onset of non-heterosexual preference.

b) Among the causal hypotheses proposed, the highest and most repeated values are always nos. 1 (sexual abuse or physical violence in childhood and/or preadolescence), 3 (dysfunctional caring on the part of the caregiver during the attachment period), 4 (unbalanced intraparental relationship) and 7 (cetified medical history of one or both parents of severe mental and/or personality disorders).

c) In the male group, the highest marking is No. 7 (cetified medical history of one or both parents of severe mental and/or personality disorders), while in the female group the values are all identical, suggesting that these causal hypotheses have a greater value in the onset of the preferred choice.

d) Such significant values leave room for a very precise causal interpretation: sexual orientations other than heterosexuality, homosexuality and bisexuality are actually adaptations to traumatic events that have an impact on the respondent's emotional and sexual sphere.

\section{2) Results obtained by PICI-1: Here is the data analysis}

a) In the male heterosexual group, psychopathological values stood at $43.96 \%$, with a greater presence of neurotic disorders, while in the female heterosexual group, values stood at $57.27 \%$, with the same greater presence as in the male group. 
b) In the male homosexual group, the psychopathological values settled at $66 \%$ with a greater presence of neurotic disorders, while in the female homosexual group, the values settled at $76.97 \%$ with the same greater presence of the male group.

c) In the male bisexual group, the psychopathological values settled at $76.44 \%$ with a greater presence of neurotic disorders, while in the female bisexual group the values settled at $70 \%$ with the same greater presence of the male group.

d) In the groups relating to the other sexual orientations, the considerations already expressed in point 1 of the conclusions apply.

The present analysis thus reveals significant dysfunctional presences in the specific traits, which become increasingly more significant when the homosexual group and the bisexual group are taken into consideration, revealing a possible psychopathological relationship of the non-heterosexual conditions (now considered orientations).

3) Results obtained from PSM-1: The following is an analysis of the data in order to answer the question "Are there any dysfunctional psychological factors that occur more frequently in any of the five identified groups?":

a) In the male (50.96\%) and female (49.91\%) heterosexual group, the presence of the marking "None of the above" emerges in half of the respondents and, although the other indicators are present, they are all fairly balanced with a greater propensity for items 2 (psychological abuse with a sexual connotation (coercion and/or submission) in childhood and/or pre-adolescence) and 4 (unbalanced intra-parental relationship).

b) In the homosexual group the same discourse made in point 1 is valid, with some variations: also point 1 (sexual abuse or physical violence in childhood and/or preadolescence) and 3 (dysfunctional caring on the part of the caregiver during the attachment period, 0-6 years) come into play in a significant way, and the presence of the marking "None of the above" is clearly inferior (8.16\% in male and $7.16 \%$ in female). This profile would lead one to think that in the homosexual group the greater presence of the dysfunctional indicators would confirm the aetiological hypothesis of a psychological nature.

c) In the bisexual group, the discourse addressed in point 2 is even more marked: all the indicators come into play except "None of the above" which is never marked, both in the male and in the female group. This profile would strengthen the conclusive hypothesis stated in point 2 .

d) In the groups relating to the other sexual orientations, the considerations already expressed in point 1 of the conclusions apply.

The topic under consideration is very thorny, more for its socio-political implications than clinical ones. Discussing the reasons for a correct inclusion or exclusion of this category in the DSM certainly represents both an excellent exercise of nomenclature, in order to also verify the quality and validity of a definition of mental illness, and to better define the related clinical picture in relation to the anamnestic profiles of the patient. In this context, it is necessary to omit the sociopolitical and anthropological aspects, and all the possible legal repercussions determined by the hypothesis confirming homosexuality as a mental pathology. In fact, there is no judgment of merit or form at stake here, as much as the exact clinical location in the cognitive and experiential sphere of the mental health professional. These considerations are completely detached and far from any form of ethical, moral, social and personal judgment or condemnation; at most, the intention is to make a de facto contribution to the clinical cause, trying to overcome any preconceptions and prejudices typical of a dysfunctional social subculture reaching out towards the isolation and ghettoization of the homosexual or bisexual person. Net from a position contrary to personal freedom, the sacrosanct civil rights struggles of the last decades are welcome, to recognize equal conditions and not discriminate against any person regarding their sexual choice. Here, therefore, at stake, there is no condemnation of a category but simply the stance of a strictly clinical evaluation, also in light of the neurobiological results of recent years. Research on the relationship between neuroscience and sexual orientation is still in its infancy, despite the numerous progress made and the finding of substantial elements capable of supposing that the neuroanatomophysiology of a not-heterosexual subject is different from a heterosexual subject. However, to date, studies have not yet clarified whether it is these differences that cause different sexual orientation or whether orientation (learned through social conditioning or genetic predisposition) shapes the anatomy and physiology of the brain by inducing the changes. It is logical and consequential to think, however, that the first solution is the most acceptable and therefore some anatomical-physiological alterations cause the subject to perceive his orientation as "not-heterosexual". On this hypothesis, still to be verified, the suspicion remains that the decision to "reroute" homosexuality and bisexuality making them become normal and sexual orientations, such as heterosexuality - can be considered forced (based on more social and political pressures, which are strictly clinical), in the light of the various neurobiological findings that have emerged in research over the past thirty years. Excluding the social and legal implications, thus suspending any moral and ethical judgment on the various positions of sexual orientation, the need to better contextualise the clinical profiles relating to the topic under examination appears interesting [1].

On the subject of the pathologization of sexual orientations other than heterosexuality, between the two theses under discussion (confirmation, on the one hand, or disconfirmation, on the other), this research suggests the "median" position that on the one hand confirms the non-pathological nature of sexual orientations other than heterosexuality per se (since there is no scientific evidence to the contrary), but on the other confirms the hypothesis that, on the basis of the person's experience, psychopathological conditions may coexist that require psychotherapeutic intervention. 
In conclusion, significant data emerges from this research in favour of the psychological aetiological hypothesis (although the writer adheres to the multi-causal hypothesis) according to which in sexual orientations other than heterosexuality there is a marked indexation of psychopathological and dysfunctional traits with respect to the heterosexual group, with the presence of the causal indicators identified in the PSM-1 (sections A, B, C, D) in an increasingly large number in the same non-heterosexual groups. These data would support the hypothesis that non-heterosexual orientations could actually be the adaptive consequence of a psychological trauma, with a strong emotional and sexual impact (including abuse, violence, neurobiological, hormonal, and somatic predispositions, affective-emotional dysregulation with reference figures, and socio-environmental and family readjustments), in itself therefore not pathological but circumstances favoring negative and unfavorable dynamics, of social and environmental matrix, such as to favor or aggravate psychopathological conditions, including mood, depressive, obsessive, somatic, personality and suicidal disorders.

\section{References}

1. Perrotta G (2020) Sexual orientations: a critical review of psychological clinical and neurobiological profiles. Clinical hypothesis of homosexua and bisexual positions. Int J Sex Reprod Health Care 3: 027-041. Link: https://bit.ly/38DtEVa

2. Perrotta G (2019) Psicologia dinamica. Luxco ed.

3. Perrotta G (2019) Psicologia clinica. Luxco ed.

4. Ellis HH (1936) Studies in the psychology of sex. New York: Random House.

5. Hirschfeld M (1952) Sexual anomalies and sexual perversions. London: Encyclopaedic Press. Link: https://bit.ly/2SUXxMl

6. Gagnon J (1975) Sex research and social change. Arch Sex Behav 4: 111-141 Link: https://bit.ly/3d3ZUnx

7. Stolberg M (2000) Self-pollution, moral reform, and the venereal trade: Notes on the sources and historical context of onania (1716). Journal of the History of Sexuality 9: 37-61. Link: https://bit.ly/3j3jy6G

8. Gilbert AN, Barkun M (1981) Disaster and sexuality. J Sex Res 17: 288-299. Link: https://bit.ly/2TOK4TA

9. Hare EH (1962) Masturbatory insanity: The history of an idea. J Ment Sci 108 2-25. Link: https://bit.ly/3qnp7yK

10. Cryle P, Downing L (2009) Feminine sexual pathologies. Journal of the History of Sexuality 18: 1-7. Link: https://bit.ly/2TXcu0S

11. Oosterhuis H (2000) Stepchildren of nature: Krafft-Ebing, psychiatry, and the making of sexual identity. Chicago: University of Chicago Press.

12. Davidson A (1991) Closing up the corpses: Diseases of sexuality and the emergence of the psychiatric style of reasoning. In G. Boolos (Ed.), Mind meaning, and method: Essays in honor of Hilary Putnam. Cambridge, England: Cambridge University Press.

13. Gall FJ (1835) On the functions of the brain and each of its parts: With observations on the possibility of determining the instincts, propensities, and talents, of the moral and intellectual dispositions of man and animals by the configuration of the brain and head. Boston: Marsh, Capen, Lyon. Link: https://bit.ly/3gUS2pw

14. Shortland M (1987) Courting the cerebellum: Early organological and phrenological views of sexuality. $\mathrm{Br} \mathrm{J}$ Hist Sci 20: 173-199. Link: https://bit.ly/3zS5PFI

15. Ellenberger $H$ (1970) The discovery of the unconscious: The history and evolution of dynamic psychiatry. New York: Basic Books.

16. James W (1887) What is an instinct? Scribner's Magazine 1: 355-365.

17. Moreau de Tours $P$ (1880) Des aberrations du sens ge'ne'sique. Paris: Libraries de la Faculte' de Me'decine.

18. Davidson A (2001) The emergence of sexuality: Historical epistemology and the formation of concepts. Cambridge, MA: Harvard University Press.

19. Gutmann P (2006) On the way to a scientia sexualis: "On the relation of the sexual system to the psyche in general and to cretinism in particular" (1826) by Joseph Haussler. Hist Psychiatry 17: 45-53. Link: https://bit.ly/350zcex

20. Waters C (2006) Sexology. In H. G. Cocks \& M. Houlbrook (Eds.), in The modern history of sexuality (pp. 41-63). London: Palgrave Macmillan.

21. Fedoroff JP (2009) The paraphilias. In M. Gelder, N. Andreasen, J. Lopez-Iber \& J. Geddes (Eds.), The new Oxford textbook of psychiatry. Oxford, England: Oxford University Press 832-842.

22. Beccalossi C (2010) Nineteenth-century European psychiatry on same-sex desires: Pathology, abnormality, normality, and the blurring of boundaries. Psychology and Sexuality 1: 226-238. Link: https://bit.ly/2Uw1yb2

23. Rimke H, Hunt A (2002) From sinners to degenerates: The medicalization of morality in the 19th century. History of the Human Sciences 15: 59-88. Link: https://bit.ly/3wRDnCe

24. Drescher J (2010) Queer diagnoses: Parallels and contrasts in the history of homosexuality, gender variance, and the Diagnostic and Statistical Manual. Arch Sex Behav 39: 427-460. Link: https://bit.ly/3xPLNdv

25. Ulrichs KH (1864) "Formatrix": Anthropologische Studien u" ber Urnische Liebe [Formatrix: Anthropological studies on Uranialove]. Leipzig, Germany: Max Spohr.

26. Krafft-Ebing R (1965) Psychopathia sexualis with special reference to the antipathic sexual instinct: A medic-forensic study. New York: Paperback Library. (Original work published 1886).

27. Rimke H, Hunt A (2002) From sinners to degenerates: The medicalization of morality in the 19th century. Hist Human Sci 15: 59-88. Link: https://bit.ly/3xL6048

28. Money J (2003) History, causality, and sexology. J Sex Res 40: 237-239. Link: https://bit.ly/35KTV2N

29. Blanchard R (2005) Early history of the concept of autogynephilia. Arch Sex Behav 34: 439-446. Link: https://bit.ly/3xIrHS5

30. Hill DB (2005) Sexuality and gender in Hirschfeld's Die Transvestiten: A case of the "elusive evidence of the ordinary". Journal of the History of Sexuality 14 316-332. Link: https://bit.ly/3qqMB5V

31. Freud S (1960a) Anonymous (Letter to an American mother). In E. Freud (Ed.), The letters of Sigmund Freud. London: Hogarth Press. (Original work published 1935) 423-424

32. Freud S (1960b) Three essays on the theory of sexuality. In J. Strachey (Ed. \& Trans.), The standard edition of the complete psychological works of Sigmund Freud. London: Hogarth Press. (Original work published 1905) 7: 123-246.

33. Freud S (1964a) Analysis terminable and interminable. In J. Strachey (Ed. \& Trans.), The standard edition of the complete psychological works of Sigmund Freud. London: Hogarth Press. (Original work published 1937) 23: 209-253.

34. Freud S (1964b) Fetishism. In J. Strachey (Ed. \& Trans.), The standard edition of the complete psychological works of Sigmund Freud. London: Hogarth Press. (Original work published 1927) 21: 153-161. 
35. De Block A (2005) Freud as an "evolutionary psychiatrist" and the foundations of a Freudian philosophy. Philosophy, Psychiatry, and Psychology 12: 315-324. Link: https://bit.ly/3vNIhik

36. Metzl JM (2004) Voyeur nation? Changing definitions of voyeurism 19502004. Harvard Review of Psychiatry 12: 127-131. Link: https://bit.ly/3vP3jx4

37. Kamieniak JP (2003) The construction of a psychopathological object: Sexual perversion in the 19th century. Revue Franc,aise de Psychanalyse 67: 249262.

38. Socarides CW (1978) The sexual deviations and the diagnostic manual American Journal of Psychotherapy 32: 414-426. Link: https://bit.ly/35M7hfe

39. Rado S (1940) Un esame critico del concetto di bisessualità. Psychosom Med 2: 459-467.

40. Rado S (1969) Psicodinamica adattativa: motivazione e controllo. Science House; New York, NY, USA.

41. Tripp CA (1975) La matrice omosessuale. Meridiano; New York, NY, USA

42. Weeks J (2000) Making sexual history. Oxford, England: Polity Press.

43. Meyerowitz J (2001) Sex research at the borders of gender: Transvestites, transsexuals. Bull Hist Med 75: 72-90. Link: https://bit.ly/3vNPU8j

44. Kinsey AC, Pomeroy WB, Martin CE (1948) Comportamento sessuale nel maschio umano. Saunders; Filadelfia, Pennsylvania, Stati Uniti.

45. Kinsey A, Pomeroy W, Martin C, Gebhard P (1953) Comportamento sessuale nella femmina umana. Saunders; Filadelfia, Pennsylvania, Stati Uniti.

46. Déttore D (2018) Trattato di psicologia e psicopatologia del comportamento sessuale, Giunti.

47. Panzeri M (2013) Psicologia della sessualità, II Mulino.

48. American Psychiatric Association (APA) (1952) Diagnostic and statistical manual: Mental disorders (DSM-I). Washington, DC

49. Shorter E (1997) A history of psychiatry: From the era of the asylum to the age of Prozac. New York: Wiley. Link: https://bit.ly/3jaUIHP

50. First M, Frances A, Pincus H (2004) DSM-IV-TR guidebook. Arlington, VA American Psychiatric Publishing

51. Kirk SA, Kutchins H (1992) The selling of the DSM: The rhetoric of science in psychiatry. New York: Aldine De Gruyter.

52. Friedman RC, Downey JI (1998) Psychoanalysis and the model of homosexuality as psychopathology: A historical overview. Am J Psychoanal 58: 249-270. Link: https://bit.ly/3jirOQH

53. Bieber I (1987) On arriving at the American Psychiatric Association decision on homosexuality. In H. Engelhardt \& A. Caplan (Eds.), Scientific controversies: Case studies in the resolution and closure of disputes in science and technology. New York: Cambridge University Press 417-436.

54. Bieber I et al (1962) Homosexuality: A psychoanalytic study of male homosexuals. New York: Basic Books.

55. Cooper R (2005) Classifying madness: A philosophical examination of the Diagnostic and Statistical Manual of Mental Disorders. Dordrecht, Netherlands: Springer. Link: https://bit.ly/2SVOnBm

56. Marmor J (1973) Homosexuality and cultural value systems. American Journal of Psychiatry 130: 1208-1209.

57. Sulloway FJ (1979) Freud, biologist of the mind: Beyond the psychoanalytic legend. Cambridge, MA: Harvard University Press.

58. Bayer R (1981) Homosexuality and American psychiatry: The politics of diagnosis. Princeton, NJ: Princeton University Press.
59. Kirk SA, Kutchins H (1992) The selling of the DSM: The rhetoric of science in psychiatry. New York: Aldine De Gruyter. Link: https://bit.ly/3gWFI83

60. Kutchins H, Kirk SA (1997) Making us crazy: DSM, the psychiatric Bible, and the creation of mental disorders. New York: Free Press. Link: https://bit.ly/3d7Ekyt

61. Spitzer R (1973) A proposal about homosexuality and the APA nomenclature: Homosexuality as an irregular form of sexual behavior and sexual orientation disturbance as a psychiatric disorder. American Journal of Psychiatry 130 1214-1216.

62. Gadpaille W (1989) Omosessualità. In: Kaplan H., Sadock BJ, editori. Manuale completo di psichiatria. 5 a ed. Williams e Wilkins; Baltimora, MD, USA.

63. Zachar P, Kendler KS (2012) La rimozione di Plutone dalla classe dei pianeti e l'omosessualità dalla classe dei disturbi psichiatrici: un confronto. Philos. Ethics Humanit Med 7: 4-10.

64. Stoller RJ et al (1973) Simposio: l'omosessualità dovrebbe essere nella nomenclatura APA? Am J Psychiatr 130: 1207-1216.

65. Spitzer RL (1981) Lo stato diagnostico dell'omosessualità nel DSM-III: una riformulazione dei problemi. Am. J. Psychiatr; 138: 210-215

66. American Psychiatric Association (APA) (1987) Diagnostic and statistical manual: Mental disorders (DSM-III). Washington, DC.

67. American Psychiatric Association (APA) (1994) Diagnostic and statistical manual: Mental disorders (DSM-IV). Washington, DC.

68. Snell RS (2010) Clinical Neuroanatomy, 7th, Lippincott Williams \& Wilkins.

69. Blumenfeld H (2010) Neuroanatomy through clinical cases 2nd, Sunderland Mass., Sinauer Associates 21.

70. Swab DF, Hofman MA (1995) Sexual differentiation of the human hypothalamus in relation to gender and sexual orientation. Trends in Neurosciences 18. Link: Link: https://bit.ly/3xJ7plf

71. LeVay S (1991) A difference in hypothalamic structure between heterosexual and homosexual men. Science 253. Link: https://bit.ly/3zOsl2u

72. Byne W, Lasco MS, Kemether E, Shinwari A, Edgar MA, et al. (2000) The interstitial nuclei of the human anterior hypothalamus: an investigation of sexual variation in volume and cell size, number and density. Brain Res 856 : 254-258. Link: https://bit.ly/3qrF4ny

73. Swaab DF, Hofman MA (1995) Sexual differentiation of the human hypothalamus in relation to gender and sexual orientation. Trends in Neurosciences 18. Link: https://bit.ly/3qlUWaR

74. Swaab DF, Hofman MA (1990) An enlarged suprachiasmatic nucleus in homosexual men. Brain Res 537: 141-148. Link: https://bit.ly/3wQ7uKe

75. Abe C, Johansson E, Allzen E, Savic I (2014) Sexual Orientation Related Differences in Cortical Thickness in Male Individuals. Plos One 9: e114721. Link: https://bit.ly/3xNtQMj

76. Hu S, Xu D, Peterson B, Wang Q, He X, et al. (2013) Association of cerebra networks in resting state with sexual preference of homosexual men: a study of regional homogeneity and functional connectivity. Plos One 8: e59426. Link: https://bit.ly/35Im1fb

77. Aste $\mathrm{N}$ et al (1998) Anatomical and neurochemical definition of the nucleus of the stria terminalis in Japanese quail (Coturnix japonica). J Comp Neurol 396.

78. Poiani A (2010) Animal Homosexuality: A Biosocial Perspective, Cambridge University Press.

79. Zhou JN, Hofman MA, Swaab DF (1995) A sex difference in the human brain and its relation to transsexuality. Nature 378: 68-70. Link: https://bit.ly/3gKR6oF 
80. Savic I, Lindström P (2008) PET and MRI show differences in cerebral asymmetry and functional connectivity between homo- and heterosexual subjects. Proceedings of the National Academy of Sciences of the United States of America 105: 9403-9408. Link: https://bit.ly/3gOB4tZ

81. Hill AK, Dawood K, Puts DA (2012) Biological Foundations of Sexual Orientation, in Handbook of Psychology and Sexual Orientation, illustrated, OUP USA. Link: https://bit.ly/3jcypf4

82. Witelson SF, Kigar DL, Scamvougeras A, Kideckel DM, Buck B, et al (2008) Corpus callosum anatomy in right-handed homosexual and heterosexual men. Arch Sex Behav 37: 857-863. Link: https://bit.ly/3vRi1mW

83. Bailey JM, Zucker KJ (1995) Childhood sex-typed behavior and sexual orientation: a conceptual analysis and quantitative review. Developmental Psychology 31: 43. Link: https://bit.ly/35MdwzG

84. LeVay S (2010) Gay, Straight, and the Reason Why: The Science of Sexual Orientation, Oxford University Press.

85. Ponseti J (2007) Homosexual Women Have Less Grey Matter in Perirhinal Cortex than Heterosexual Women. PLoS One 2: e762. Link: https://bit.ly/3wPMK57

86. Friedman RC (1990) Male Homosexuality, New Haven, Yale University Press 312.

87. Guillamon A, Junque C, Gómez-Gil E (2016) A Review of the Status of Brain Structure Research in Transsexualism. Arch Sex Behav 45: 1615-11648. Link: https://bit.ly/3xIJUz5

88. Berglund H, Lindström P, Savic I (2006) Brain response to putative pheromones in lesbian women. Proc Natl Acad Sci U S A 103: 8269-8274. Link: https://bit.ly/3gOBlaP

89. Savic I, Berglund H, Lindström P (2005) Brain response to putative pheromones in homosexual men. Proc Natl Acad Sci U S A 102. Link: https://bit.ly/3j3osR

90. Safron A, Barch B, Bailey JM, Gitelman DR, Parrish TB, et al. (2007) Neural correlates of sexual arousal in homosexual and heterosexual men. Behav Neurosci 121: 237-248. Link: https://bit.ly/2SP2BT5

91. Paul T, Schiffer B, Zwarg T, Krüger TH, Karama S, et al. (2008) Brain response to visual sexual stimuli in heterosexual and homosexual males. Human Brain Mapping 29: 726-735. Link: https://bit.ly/2SV5VMc

92. Hu SH, Wei N, Wang QD, Yan LQ, Wei EQ, et al. (2008) Patterns of brain activation during visually evoked sexual arousal differ between homosexual and heterosexual men. AJNR Am J Neuroradiol 29. Link: https://bit.ly/3vZgYl

93. Ponseti J, Bosinski HA, Wolff S, Peller M, Jansen O, et al. (2006) A functional endophenotype for sexual orientation in humans. Neurolmage 33. Link: https://bit.ly/3gMPz1h

94. Kranz F, Ishai A (2006) Face Perception Is Modulated by Sexual Preference. Current Biol 16: 63-68. Link: https://bit.ly/3qkbC2v

95. Sanders G, Wright M (1997) Sexual orientation differences in cerebral asymmetry and in the performance of sexually dimorphic cognitive and motor tasks. Archives of Sexual Behavior 26. Link: https://bit.ly/3xJbRqr

96. Duffy SM, Rusbult CE (1985) Satisfaction and commitment in homosexual and heterosexual relationships. J Homosex 12: 1-23. Link: https://bit.ly/3zPGixe

97. Kinnunen LH, Moltz H, Metz J e Cooper M (2004) Differential brain activation in exclusively homosexual and heterosexual men produced by the selective serotonin reuptake inhibitor, fluoxetine. Brain Res 1024. Link: https://bit.ly/3d72us

98. Perrotta G (2019) Paraphilic disorder: definition, contexts and clinical strategies. J Neuro Research 1: 4.

99. Perrotta G (2019) Anxiety disorders: definitions, contexts, neural correlates and strategic therapy. J Neur Neurosci 6: 046. Link: https://bit.ly/2WSmiaT
100. Perrotta G (2019) Neural correlates in eating disorders: Definition, contexts and clinical strategies. J Pub Health Catalog 2: 137-148. Link: https://bit.ly/3mWmf8s

101. Perrotta G (2019) Post-traumatic stress disorder: Definition, contexts, neural correlations and cognitive-behavioral therapy. J Pub Health Catalog 2: 40-47. Link: https://bit.ly/3rvaCc6

102. Perrotta G (2019) Depressive disorders: Definitions, contexts, differentia diagnosis, neural correlates and clinical strategies. Arch Depress Anxiety 5 009-033. Link: https://bit.ly/2KADvDm

103. Perrotta G (2019) Panic disorder: definitions, contexts, neural correlates and clinical strategies. Current Trends in Clinical \& Medical Sciences 1. Link: https://bit.ly/38IG6D5

104. Perrotta G (2019) Obsessive-Compulsive Disorder: definition, contexts, neural correlates and clinical strategies. Cientific Journal of Neurology 1 : 08-16. Link: https://bit.ly/3pxNbNu

105. Perrotta G (2019) Behavioral addiction disorder: definition, classifications, clinical contexts, neural correlates and clinical strategies. J Addi Adol Beh 2. Link: https://bit.ly/3rAT9ip

106. Perrotta G (2020) Suicidal risk: definition, contexts, differential diagnosis, neural correlates and clinical strategies. J Neuroscience Neurological Surgery 6: 114. Link: https://bit.ly/3aMqcu5

107. Perrotta G (2020) The strategic clinical model in psychotherapy: theoretical and practical profiles. J Addi Adol Behav 3: 5. Link: https://bit.ly/3aPMx9X

108. Tin LG (2003) The dictionary of homophobia, Arsenal Ed.

109. Perrotta G (2019) Psicologia generale. Luxco ed

110. Perrotta G (2021) Perrotta Individual Sexual Matrix Questionnaire (PSM1). The new clinical questionnaire to investigate the main areas of the individual sexual matrix. Int J Sex Reprod Health Care 4: 013-021. Link: https://bit.ly/3oTua9o

111. Perrotta G (2020) Perrotta Integrative Clinical Interview LK ed., I ed., pag 270

112. Perrotta G (2020) The structural and functional concepts of personality: The new Integrative Psychodynamic Model (IPM), the new Psychodiagnostic Investigation Model (PIM) and the two clinical interviews for the analysis of personality disorders (Perrotta Integrative Clinical Interview or $\mathrm{PICl}$ ) for adults and teenagers (1TA version) and children (1C version), Psychiatry Peertechz, E-book. Link: https://bit.ly/2SqQevV

113. Perrotta G (2020) First revision of the Psychodiagnostic Investigation Mode (PIM-1R) and elaboration proposal of a clinical interview for the analysis of personality disorders (Perrotta Integrative Clinical Interview or PICl-1) for adults. Teenagers and Children Psychiatry Peertechz, E-book. Link: https://bit.ly/2MQe3dY

114. Bayer R (1987) Homosexuality and American Psychiatry: The Politics of Diagnosis, Princeton, Princeton University Press. Link: https://bit.ly/3d5eifa

115. Fernandez D (1992) II ratto di Ganimede, Bompiani.

116. Hooker $E$ (1957) The adjustment of the male overt homosexual. Journal of Projective Techniques 21: 18-31. Link: https://bit.ly/3gKON4Z

117. Rahman Q (2005) The neurodevelopment of human sexual orientation. Neuroscience \& Biobehavioral Reviews 29. Link: https://bit.ly/3xPDFK1

118. Ganna A, Verweij KJH, Nivard MG, Maier R, Wedow R, et al. (2004) Largescale GWAS reveals insights into the genetic architecture of same-sex sexual behaviour. Science 365: eaat7693. Link: https://bit.ly/3j3dxXE

119. Williams TJ, Pepitone ME, Christensen SE, Cooke BM, Huberman AD, et al. (2000) Finger-length ratios and sexual orientation. Nature 404: 455-456. Link: https://bit.ly/3gZUkU8

Citation: Perrotta G (2021) Clinical evidence in sexual orientations: definitions, neurobiological profiles, and psychological implications. Ann Psychiatry Treatm 5(1) 043-053. DOI: https://dx.doi.org/10.17352/apt.000030 
120. Swaab DF (2004) Sexual differentiation of the human brain: relevance for gender identity, transsexualism and sexual orientation. Gynecol Endocrinol 19: 301-312. Link: https://bit.ly/3zRGCeT

121. Tortorice $J L$ (2002) Written on the body: butch/femme lesbian gender identity and biological correlates. Rutgers Ph.D. Dissertation. Link: https://bit.ly/35IrKkT

122. McFadden D, Shubel E (2002) Relative lengths of fingers and toes in human males and females. Hormones and Behavior 42: 492-500. Link: https://bit.ly/3gZP8Q6

123. Hall LS, Love CT (2003) Finger-length ratios in female monozygotic twins discordant for sexual orientation. Archives of Sexual Behavior 32: 23-28. Link: https://bit.ly/2UjvPtp

124. Rahman Q, Wilson GD (2003) Sexual orientation and the 2nd to 4th finger length ratio: evidence for organising effects of sex hormones or developmental instability?. Psychoneuroendocrinology 28: 288-303. Link Link: https://bit.ly/3vOAvER

125. Csathó A, Osváth A, Bicsák E, Karádi K, Manning J, et al. (2003) Sex role identity related to the ratio of second to fourth digit length in women. Biol Psychol 62: 147-156. Link: https://bit.ly/3gUkIFT

126. Putz D, Gaulin SJC, Sporter RJ, McBurney DH (2004) Sex hormones and finger lengthWhat does 2D:4D indicate?. Evolution and Human Behavior 25 182-199. Link: https://bit.ly/3d4C9M4

127. Rahman Q (2005) Fluctuating asymmetry, second to fourth finger length ratios and human sexual orientation. Psychoneuroendocrinology 30: 382391. Link: https://bit.ly/3xLgjVC

128. Kraemer B, Noll T, Delsignore A, Milos G, Schnyder U, et al. (2006) Finger length ratio (2D:4D) and dimensions of sexual orientation. Neuropsychobiology 53: 201-214. Link: https://bit.ly/3gVTOqh

129. Wallien MS, Zucker KJ, Steensma TD, Cohen-Kettenis PT (2008) 2D:4D finger-length ratios in children and adults with gender identity disorder. Hormones and Behavior 54: 450-454. Link: https://bit.ly/3qkPYLR

130. Bogaert AF (2006) Biological versus nonbiological older brothers and men's sexual orientation. Proceedings of the National Academy of Sciences of the United States of America 103: 10771-10774. Link: https://bit.ly/3zRwJOw

131. Bogaert AF, Skorska M (2011) Sexual orientation, fraternal birth order, and the maternal immune hypothesis: a review. Front Neuroendocrinol 32: 247254. Link: https://bit.ly/3zS1Nx4

132. Cantor JM, Blanchard R, Paterson AD, Bogaert AF (2002) How many gay men owe their sexual orientation to fraternal birth order?. Arch Sex Behav 31: 63-71. Link: https://bit.ly/3gMYPCA

133. Blanchard R, Bogaert AF (1996) Homosexuality in men and number of olde brothers. Am J Psychiatry 153: 27-31. Link: https://bit.ly/3d4ZIKd

134. Blanchard R, Bogaert AF (2004) Proportion of homosexual men who owe their sexual orientation to fraternal birth order: An estimate based on two national probability samples. Am J Hum Biol 16: 151-157. Link: https://bit.ly/3gVJZsu

135. Blanchard R, Lippa RA (2007) Birth order, sibling sex ratio, handedness, and sexual orientation of male and female participants in a BBC internet research project. Archives of Sexual Behavior 36: 163-176. Link: https://bit.ly/3j6NIGi

136. Rahman Q (2005) Fluctuating asymmetry, 2nd to 4th finger length ratios and human sexual orientation. Psychoneuroendocrinology 30: 382-391. Link: https://bit.ly/3xLkKQg
137. Mustanski BS, Bailey JM, Kaspar S (2002) Dermatoglyphics, handedness, sex, and sexual orientation. Arch Sex Behav 31: 113-122. Link: https://bit.ly/2SPL9xO

138. LeVay S (2010) Gay, Straight, and the Reason Why: The Science of Sexual Orientation. Oxford University Press. Link: https://bit.ly/3qhWfYu

139. Martin JT, Puts DA, Breedlove SM (2008) Hand Asymmetry in Heterosexual and Homosexual Men and Women: Relationship to 2D:4D Digit Ratios and Other Sexually Dimorphic Anatomical Traits. Arch Sex Behav 37: 119-132. Link: https://bit.ly/3wLPQXY

140. Perrotta G (2020) Bisexuality: definition, humanistic profiles, neura correlates and clinical hypotheses. J Neuroscience and Neurological Surgery 6. Link: https://bit.ly/2L6VXmA

141. Perrotta G (2019) The reality plan and the subjective construction of one's perception: the strategic theoretical model among sensations, perceptions, defence mechanisms, needs, personal constructs, beliefs system, social influences and systematic errors. J Clinical Research and Reports 1. Link: Link: https://bit.ly/3b34baH

142. Perrotta G (2020) Psychological trauma: definition, clinical contexts, neura correlations and therapeutic approaches. Curr Res Psychiatry Brain Disord: CRPBD-100006. Link: https://bit.ly/37UD3bz

143. Perrotta G (2020) Human mechanisms of psychological defence: definition, historical and psychodynamic contexts, classifications and clinical profiles. Int J Neurorehabilitation Eng 7: 1. Link: https://bit.ly/2L0I5dJ

144. Perrotta G (2020) Dysfunctional attachment and psychopathological outcomes in childhood and adulthood. Open J Trauma 4: 012-021. Link: https://bit.ly/2Mi2ThB

145. Perrotta G (2020) Neonatal and infantile abuse in a family setting. Open $\mathrm{J}$ Pediatr Child Health 5: 034-042. Link: https://bit.ly/2KApVQo

146. Perrotta G (2020) Dysfunctional sexual behaviors: definition, clinical contexts, neurobiological profiles and treatments. Int J Sex Reprod Health Care 3: 061-069. Link: https://bit.ly/3hxT4aU

\section{Peertechz Publications}

\section{Highlights}

* Signatory publisher of ORCID

* Signatory Publisher of DORA (San Francisco Declaration on Research Assessment)

* Articles archived in worlds' renowned service providers such as Portico, CNKI, AGRIS, TDNet, Base (Bielefeld University Library), CrossRef, Scilit, J-Gate etc.

* Journals indexed in ICMJE, SHERPA/ROMEO, Google Scholar etc.

- OAI-PMH (Open Archives Initiative Protocol for Metadata Harvesting)

* Dedicated Editorial Board for every journal

* Accurate and rapid peer-review process

* Increased citations of published articles through promotions

* Reduced timeline for article publication

Submit your articles and experience a new surge in publication services (https://www.peertechz.com/submission).

Copyright: ( 2021 Perrotta G. This is an open-access article distributed under the terms of the Creative Commons Attribution License, which permits unrestricted use distribution, and reproduction in any medium, provided the original author and source are credited. 